\title{
Metocean Environment for Aquaculture Seaweed Farming System
}

\author{
Sulaiman 00* \\ School of Ocean Engineering, Malaysia
}

Submission: March 08, 2017; Published: June 08, 2017

*Corresponding author: Sulaiman 00, University Malaysia Terengganu, School of Ocean Engineering, 21030, Kuala Terengganu, Malaysia, Email: Oolanrewaju8@gmail.com

\section{Abstract}

The study and analysis of metocean data is essential in predicting future environmental conditions. In relation withdesign nearshore structure for of seaweed cultivation, this study focuses on the collection and analysis of metocean data of potential sites in Malaysia so as to prevent under-designing and over-designing of the structure.The study investigates the metocean environment for the spatial design and monitoring of a seaweed aquaculture farm at monsoons proton East Coastal region

\section{Introduction}

Recent trends have shown that companies are becoming more involved in joint industry projects (JIP) when planning on a certain project which is beneficial in saving costs but having risks such as losing shared equipment and data altogether as well as having to wait for the technical scope for a significant amount of time and getting many contracts signed and agreed. However, when it comes to collecting metocean data, which is not sensitive or confidential amongst companies, companies are encouraged easily to work together to gather such data.

Seaweeds are comprised of many species that are native to certain habitats with specific environmental conditions. Hence, it is essential for one study and analyse potential locations for deployment of any project, especially a project that involves spatial planning. Seaweeds are sensitive to environmental changes and thus, require deep analysing of the location to ensure the survival of the seaweed farm. Metocean data of a certain region can assist in determining the design criteria of offshore or nearshore infrastructures which can prevent structural failure and even overdesigning.

The paper highlights Collection of historical metocean data of potential sites and hydrodynamic simulation of the metocean data to enhance management of deployment of seaweed aquaculture farm.

\section{Background}

Metocean data collection are normally collected using measuring instruments such as using buoys and wave radars which aids in observing wave heights and wave directions of a specific region as well as installing anemometer on offshore platforms to measure wind speed and direction. Wave radars can also be applied for structural monitoring, weather forecasting, sea state assessment for operations, water level observations and wind farm monitoring. Instruments are prone to malfunction and thus, missing data is inevitable. Yet, the fragmented data that are acquired from the instruments are used for processing and analyzing. The validation of the data consisted of comparing continuous wave hindcast against NOAA data buoy sea state measurements at one location while comparing the data with TOPEX and ERS satellite altimeter wave height data for the whole basin. The verification was on paired data and probability distributions. Methodology of metocean data and environmental data factors which affects the survivability and growth of the native seaweed species for vulnerable east coast of Malaysia is investigated (Figure 1).

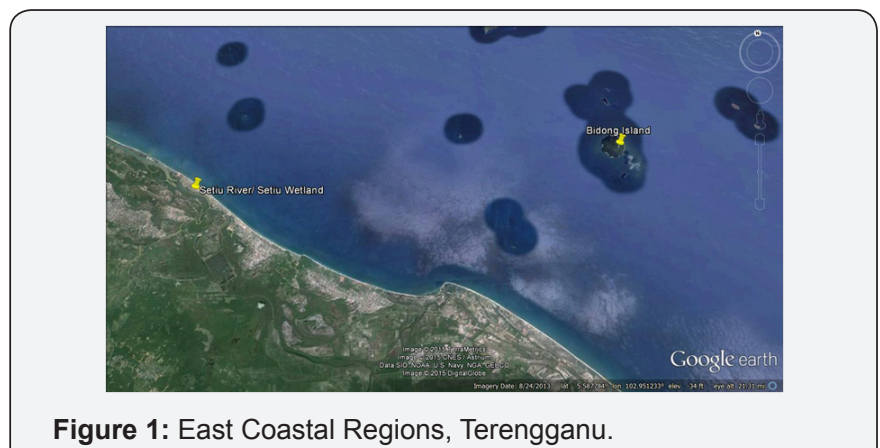

Figure 1: East Coastal Regions, Terengganu. 
The design of offshore or nearshore structure can bring about safety issues so it is essential for the right data to be gathered and analysed that can be understood by engineers when planning an offshore project. The design criteria must be able to fulfill the requirements of being conservative for today's solutions and simultaneously have room for additional modifications to the structure in the future [1].

Metocean data studies usually involves gathering the relevant historical metocean data that ranges for 20 to 30 years at least from reliable sources based on the venue of the potential sites. Besides, metocean data collection of the present conditions of the potential sites is also carried out via measuring instruments that are available and reliable to use. After collecting the metocean data, the data will be processed and analysed via numerical and hindcast modelling. For this study, MIKE 21/3 HD FM software is used for analyzing, simulating and calibrating the models (Table $1 \& 2$ ).

Table 1: Simulation Period : April 2014 (With Wind Forcing; CFSR).

\begin{tabular}{|c|c|c|c|c|c|}
\hline No & Setup & Remarks & Tidal Station & RMSE (\%) & Stimulation Time \\
\hline \multirow{9}{*}{4} & \multirow{9}{*}{$\begin{array}{c}\text { Seeweed_EastCoast_ } \\
\text { Penninsular } \\
\text { _Mesh03_UTM48_ } \\
\text { CFSR_April2014__ } \\
\text { Calibo1 }\end{array}$} & $\begin{array}{l}\text { Resistance Map } \\
32 \text { was used. } \\
{\left[5\left(\mathrm{~m}^{\wedge} 1 / 3\right) / \mathrm{s}\right) \text { at }} \\
\text { boundaries }]\end{array}$ & Kulala Dungun & 10 & \multirow{9}{*}{$16 \mathrm{hrs}$} \\
\hline & & $\begin{array}{l}\text { Used KMS Boundary } \\
\text { Conditions (Wind } \\
\text { Driven) }\end{array}$ & Chendering & 12 & \\
\hline & & $\begin{array}{l}\text { Compared } 6 \text { (all) } \\
\text { tidal stations }\end{array}$ & Kulala Terengganu & 12 & \\
\hline & & $\begin{array}{l}\text { Compared Currecnt } \\
\text { Velocity and } \\
\text { Direction }\end{array}$ & Setiu & 14 & \\
\hline & & RMSE: $25 \%$ and $36 \%$ & Sungai Besut & 13 & \\
\hline & & Compared U Velocity & Tumpat & 15 & \\
\hline & & RMSE: $13 \%$ & & & \\
\hline & & Compared V velocity & & & \\
\hline & & RMSE: $42 \%$ & & & \\
\hline \multirow{7}{*}{5} & \multirow{7}{*}{$\begin{array}{c}\text { Seeweed_EastCoast_ } \\
\text { Penninsular } \\
\text { _Mesh03_UTM48_ } \\
\text { CFSR_April2014__ } \\
\text { Calibo2 }\end{array}$} & $\begin{array}{c}\text { Resistance Map } 32 \\
\text { was used. }\end{array}$ & Kulala Dungun & 10 & \multirow{7}{*}{$18 \mathrm{hrs}$} \\
\hline & & $\begin{array}{l}\text { Used KMS Boundary } \\
\text { Conditions (Wind } \\
\text { Driven) }\end{array}$ & Chendering & 12 & \\
\hline & & $\begin{array}{l}\text { Included Tgganu } \\
\text { Wind Forcing }\end{array}$ & Kulala Terengganu & 12 & \\
\hline & & $\begin{array}{l}\text { Compared } 6 \text { (all) } \\
\text { tidal stations }\end{array}$ & Setiu & 14 & \\
\hline & & $\begin{array}{l}\text { Compared Currecnt } \\
\text { Velocity and } \\
\text { Direction }\end{array}$ & Sungai Besut & 13 & \\
\hline & & RMSE: $25 \%$ and $35 \%$ & Tumpat & 15 & \\
\hline & & Compared U Velocity & & & \\
\hline
\end{tabular}


Fisheries and Oceanography Open Access Journal

\begin{tabular}{|c|c|c|c|c|c|}
\hline \multirow{10}{*}{6} & \multirow{10}{*}{$\begin{array}{c}\text { Seeweed_EastCoast_ } \\
\text { Penninsular_Mesh03_ } \\
\text { UTM48_CFSR_ } \\
\text { April2014_Calibo3 }\end{array}$} & $\begin{array}{c}\text { Sbh and Swak Map } \\
\text { is used }\end{array}$ & Kulala Dungun & 10 & \multirow{10}{*}{$15 \mathrm{hrs}$} \\
\hline & & $\begin{array}{l}\text { Used KMS Boundary } \\
\text { Conditions (Wind } \\
\text { Driven) }\end{array}$ & Chendering & 12 & \\
\hline & & $\begin{array}{l}\text { Included Tgganu } \\
\text { Wind Forcing }\end{array}$ & Kulala Terengganu & 12 & \\
\hline & & $\begin{array}{c}\text { Compared } 6 \text { (all) tidal } \\
\text { stations }\end{array}$ & Setiu & 14 & \\
\hline & & $\begin{array}{l}\text { Compared Currecnt } \\
\text { Velocity and Direction }\end{array}$ & Sungai Besut & 13 & \\
\hline & & RMSE: $25 \%$ and $35 \%$ & Tumpat & 15 & \\
\hline & & Compared U Velocity & & & \\
\hline & & RMSE: $13 \%$ & & & \\
\hline & & Compared V velocity & & & \\
\hline & & RMSE: $44 \%$ & & & \\
\hline \multirow{8}{*}{7} & \multirow{8}{*}{$\begin{array}{c}\text { Seeweed_EastCoast_ } \\
\text { Penninsular_Mesh03_ } \\
\text { UTM48_CFSR_ } \\
\text { April2014_Calibo4 }\end{array}$} & $\begin{array}{l}\text { Resistance Map } \\
32 \text { was used. } \\
{\left[5\left(\mathrm{~m}^{\wedge} 1 / 3\right) / \mathrm{s}\right) \text { at }} \\
\text { boundaries }]\end{array}$ & Kulala Dungun & 10 & \multirow{8}{*}{$17 \mathrm{hrs}$} \\
\hline & & $\begin{array}{l}\text { Used KMS Boundary } \\
\text { Conditions (Wind } \\
\text { Driven) }\end{array}$ & Chendering & 12 & \\
\hline & & $\begin{array}{l}\text { Included Tgganu } \\
\text { Wind Forcing }\end{array}$ & Kulala Terengganu & 12 & \\
\hline & & $\begin{array}{c}\text { Compared } 6 \text { (all) tidal } \\
\text { stations }\end{array}$ & Setiu & 14 & \\
\hline & & $\begin{array}{l}\text { Compared Currecnt } \\
\text { Velocity and Direction }\end{array}$ & Sungai Besut & 13 & \\
\hline & & RMSE: $25 \%$ and $36 \%$ & Tumpat & 15 & \\
\hline & & Compared U Velocity & & & \\
\hline & & RMSE: $13 \%$ & & & \\
\hline
\end{tabular}

\section{Table 2}

\begin{tabular}{|c|c|}
\hline \multicolumn{2}{|c|}{ Drag Force for Mooring Components and Seaweed } \\
\hline Current Speed (m/s) & Drag Force \\
\hline 1 to 1.5 & Minimal \\
\hline 2 to 3 & Large \\
\hline$>3$ & Large (Intolerable) \\
\hline Current Direction (Degree) & Max Drag Force \\
\hline 0 to 10 & Ultimate limit state \\
\hline 90 & Accidental limit state \\
\hline
\end{tabular}

The parameters of the data that are used for hindcast modelling will include wind, wave and current. The wind data will comprise of speed and direction, the wave data will comprise of height and lastly, the current will comprise of speed and direction. Moreover, there are several sources where metocean data of specific regions can be obtained namely, the University Corporation for Atmospheric Research (UCAR) and the National Center for Atmospheric Research (NCAR). The institutions provide a number of suggested products or programs that have online databases on certain ocean parameters such as the Climate Forecast System Reanalysis (CFSR) (National Center for Atmospheric Research Staff, 2014), Surface Flux and Meteorological Dataset: National Oceanography Centre (NOC) V2.0 (Kent \& National Center for Atmospheric Research Staff, 2014), Global Sea Level from TOPEX \& Jason Altimetry [2-4],

\section{Conclusion}

The Study investigates the metocean environment for the spatial design and monitoring of a seaweed aquaculture seaweed farm for Eastern Coast near, Terengganu. Historical metocean data (wave, wind and current) of potential sites from reliable sources and metocean data of present conditions of potential sites via measuring instruments were collected processed and analysed. Then model simulate and calibrate the environment based on the data collected for the potential sites.

\section{Acknowledgement}

The author acknowledges F. Arina for her direct contribution and DHI for the support and training. 


\section{References}

1. Shaw C, Shell Global Solutions Offshore Industry Requirements and Recent Metocean Technology Developments ( $1^{\text {st }}$ edn), Advances In The Applications Of Marine Climatology, pp. 229-233.

2. National Center for Atmospheric Research Staff (2013) Global Sea Level From Topex \& Jason Altimetry.
3. Department of Irrigation and Drainage Malaysia (2001) Guidelines for Preparation of Coastal Engineering Hydraulic Study and Impact Evaluation $\left(5^{\text {th }} \mathrm{edn}\right)$.

4. Oceanweather (2015) OceanweatherInc: MetOcean Studies: SEAFINE, USA.

\section{Your next submission with Juniper Publishers will reach you the below assets}

- Quality Editorial service

- Swift Peer Review

- Reprints availability

- E-prints Service

- Manuscript Podcast for convenient understanding

- Global attainment for your research

- Manuscript accessibility in different formats

( Pdf, E-pub, Full Text, Audio)

- Unceasing customer service

Track the below URL for one-step submission https://juniperpublishers.com/online-submission.php 